\title{
Response of benthic microbial mats to drifting green algal mats
}

\author{
Kristina Sundbäck*, Lena Carlson, Claes Nilsson, Benno Jönsson**, Angela Wulff, \\ Svante Odmark
}

Department of Marine Botany, Göteborg University, Carl Skottsbergs Gata 22b, S-413 19 Göteborg, Sweden

\begin{abstract}
Eutrophication has increased the amount of drifting ephemeral algae in shallow coastal bays. These floating algal mats can be expected to change the light climate of benthic primary producers and to induce oxygen deficiency, which may increase nutrient release from the sediment. The impact of healthy green algal mats, mainly Enteromorpha spp., on benthic microbial mats was studied in five 2 to $6 \mathrm{wk}$ outdoor experiments by incubating intact sediment below natural green algal mats from a microtidal bay on the west coast of Sweden. The microbial mats were cohesive and dominated by large motile diatoms, mainly Gyrosigma balticum. Estimates of response were based on biomass and composition of microalgae and meiofauna, biomass of bacteria, chlorophyll a content, pigment ratios, primary productivity, sediment oxygen microprofiles, and inorganic nutrient fluxes. Occasional field measurements of light, oxygen, and inorganic nutrients above and below green algal mats were made. The results suggest that benthic diatom-dominated microbial mats need not be outcompeted by average amounts of healthy green algae during the growth season. Despite strongly reduced light below the green algae, no adverse effects on the biomass of microorganisms were found. Iither no quantitative effects were found at all, or an initial stimulus of microalgal biomass was observed. The only consistent pattern reflecting treatment was that the sediment surface below the green algae became dark brown, while cores with no green algal cover became greyısh. This appeared to be caused by a different vertical position of diatoms within the sediment. Sediment oxygen profiles indicated a higher photosynthetic efficiency below the green algal mats, indicating light acclimation of the microalgae. It is suggested that shade adaptation and sediment nutrient supply enable the diatoms, and other microbiota, to coexist with moderate amounts of healthy druft algae. Both in situ and in the experiments, algal photosynthesis kept oxygen concentrations above critical values, even at night, thereby preventing redox-related nutrient outflux from the sediment. The results hint at some not yet fully understood mechanisms of diatom-dominated microbial mats for adaptıng to life below another algal mat. Although light-induced orientation and vertical movement of diatoms appear to play a major role in this acclimation, the role of other mechanisms, such as heterotrophic nutrition, should be examined.
\end{abstract}

KEY WORDS: Sediment. Diatoms - Meiofauna Chlorophyll - Motility Light Nutrients Oxygen Gyrosigma

\section{INTRODUCTION}

Coastal shallow-water sediments are highly productive areas, providing foraging and breeding grounds for many commercially important fish species, as well as their prey (e.g. Pihl 1989 and references therein).

\footnotetext{
-E-mail: kristina.sundback@marbot.gu.se

-Present address: Tjärnö Marine Biological Laboratory, S-452 96 Stromstad, Sweden
}

The most important autochthonous primary producing components of these habitats are seagrasses and sediment-associated microalgae. However, drifting mats of ephemeral macroalgae have become a common sight in shallow bays, the phenomenon being largely related to coastal eutrophication (e.g. Rosenberg et al. 1990, Sfriso et al. 1992, McComb \& Humphries 1992 and references thereinj. On the Swedish west coast, maximum amounts of drifting green algae are found during the period June-August, when sheltered bays can be 
entirely covered by a floating green carpet (Pihl et al in press) These mats are generally considered a nuisance. They hinder recreation on beaches and create acute problems such as bottom anoxia. In the long run, they may reduce the ecological complexity of the shallow areas, thereby fundamentally changing benthic food webs, which in turn affects fish and macrofauna recruitment (Olafsson 1988, Isaksson \& Pihl 1992).

Floating macroalgal mats can be expected to influence the underlying sediment by changing the light climate of benthic primary producers and by creating hypoxic conditions. Negative effects of drifting algal banks on seagrasses have been previously documented (e.g Thybo-Christesen et al. 1993, den Hartog 1994), whereas the impact on sediment-associated microalgae, or other microbiota, has been less studied Instead, the sediment has mainly been looked upon as an important nutrient source for the growth and maintenance of the drift algae. This idea is based on the fact that increased respiration and decomposition within the algal mats can lead to oxygen deficiency. Anoxia leads to redox-dependent release of phosphate and ammonium from the sediment, particularly at night, when oxygen demand is not matched by photosynthetic oxygen production (e.g. Lavery \& McComb 1991, Jeffrey et al. 19951.

This study was inspired by the observation that welldeveloped and cohesive benthic microbial mats occurred in the same shallow microtidal bay where floating green algal mats were also common during summer. The microbial mats were dominated by large (300 to $400 \mu \mathrm{m}$ ) motile epipelic diatoms (cf. Jönsson et al. 1994). These observations raised the question of whether the benthic microbial mats could be outcompeted by the floating 'newcomers'. On the whole, there are still very few studies on the competition between different types of algal communities (Fong et al. 1993).

To study how microbial mats respond when they are covered by floating green algal mats, we conducted a series of outdoor experiments in which intact sediment cores were incubated under natural green algal mats. We wanted to focus specifically on a situation where the drifting mats were healthy and growing, not on effects of decaying algal banks. Questions addressed were: Are benthic microalgae affected or can these 2 types of algal mats co-exist during the growth season? Are heterotrophic components of the microbial mat, for example meiofauna and bacteria, affected? The main variables considered were biomass and composition of microalgae and meiofauna, biomass of bacteria, chlorophyll a (chl a) content, pigment ratios, sediment oxygen profiles, and inorganic nutrient fluxes. Occasional field measurements of light, temperature and oxygen, as well as inorganic nutrient concentrations, above and below green algal mats were made.

\section{MATERIAL AND METHODS}

Study area. The sampling site, Daftö Bay, is a sheltered shallow $(0.5 \mathrm{~m})$ bay with a several meter wide, $1 \mathrm{~m}$ deep central trench, near the Tjärnö Marine Biological Laboratory on the west coast of Sweden $\left(58^{\circ} 52^{\prime} \mathrm{N}, 11^{\circ} 09^{\prime} \mathrm{E}\right)$. The maximum tidal amplitude of the area is only $\sim 30 \mathrm{~cm}$. The sediment is soft, the main benthic primary producers being rooted plants (Ruppia maritima L. and Zostera marina L.) and benthic microalgae. The latter form cohesive microbial mats during summer. During summer, green algae mainly exist as floating carpets. In June 1993, when the study began, most of the bay was covered by healthy-looking green algal mats, with the exception of the deeper central trench, where water flow was faster The microbial mats were particularly well developed in the trench. In summer 1994 the green algal mats were less well developed.

Field measurements. For background information, light, temperature and concentrations of oxygen and inorganic nutrients were occasionally measured in the field in 1993. Measurements were made during daytime on 3 occasions (June 14, 18,29) and both during day and night on 1 occasion (July 5-6). Night values were measured just before sunrise (at $04: 30 \mathrm{~h}$ ), and day values at 18:30 h, as previous diurnal. measurements suggested that maximum oxygen values are usually found in early evening and minimum values in early morning (e.g. Sundbäck et al. 1990). Measurements were made at the water surface (above green algal mats), just below the green algal mats and close to the sediment surface. Photosynthetically active radiation (PAR) was measured with a quantum scalar irradiance meter (Biospherical Instruments). Temperature and oxygen were measured with an oxygen sensor (OxyGuard Mk III) For nutrient analyses see below.

Experiments. Intact sediment cores were incubated in an outdoor flow-through system with and without the addition of natural green algal mats (Fig 1). Five experiments, lasting between 11 and $41 \mathrm{~d}$, were conducted during the period June-August in 1993 (Expts A, B, C) and 1994 (Expts D, E). Duration of the experiments, treatments and measured variables are shown in Table 1 The range of surface temperatures during this period was 16 to $17.5^{\circ} \mathrm{C}$ in 1993 and 14 to $22.5^{\circ} \mathrm{C}$ in 1994. While Expt A focused on both nutrient flux and response of microorganisms, the subsequent 4 experiments considered only microorganisms, with emphasis on microalgae. Algal and meiofaunal biomass and sediment chl a content were measured in all experiments, whereas inorganic nutrients ( $\mathrm{N}, \mathrm{P}$ and $\mathrm{Si}$ ) and bacterial biomass were measured only in Expt $\mathrm{A}$ (Table 1). In Expts C, D and E, sediment oxygen profiles were measured (using microsensors) as indicators of photosyn- 
thetic oxygenation. In Expt D, primary productivity $\left({ }^{14} \mathrm{C}\right.$ incorporation) and pigment ratios (determined using high-performance liquid chromatography, HPLC) were also measured.

Sediment core collection: Sediment cores for all experiments were collected from the trench in Daftö Bay at a water depth of ca $1 \mathrm{~m}$, using transparent PVC tubes (i.d. $68 \mathrm{~mm}$, length 85 or $100 \mathrm{~mm}$ ). The sediment was muddy, with a water content of $\sim 68 \%$ for the top $5 \mathrm{~mm}$, and covered by a brown cohesive microbial mat. Pieces (ca $20 \times 25 \mathrm{~cm}$ ) of healthy looking green algal mats, consisting mainly of Enteromorpha spp., were cut out using scissors and lifted carefully into troughs filled with surface water. At the laboratory, the green algae were kept cool in running seawater for a few hours. The sediment cores were immediately placed in outdoor flow-through troughs (see below).

Experimental set-up: The outdoor flow-through system consisted of six 401 white square troughs $(47 \times$ $40 \mathrm{~cm}$, height $22 \mathrm{~cm}$ ) placed on a jetty outside the laboratory (Fig. 1a). Each trough had a separate supply of filtered water flowing through it (cotton cartridge filters, 50 and $1 \mu \mathrm{m}$ ), which was continuously pumped up from $\sim 1 \mathrm{~m}$ depth beside the jetty and into a supply tank with overflow (Fig. 1a). To produce an even, homogeneous flow in each trough (checked by fluorescein dye), the water was routed through holes in a horizontal PVC tube along the longer inner wall of each trough ('flow disperser' in Fig. 1c). The flow rate was -16 to $18 \mathrm{l} \mathrm{h}^{-1}$, equalling a turnover time of 10 times per $24 \mathrm{~h}$. The oxygen saturation in the inflowing water was $\sim 90 \%$. In Expts A, B and C, a transparent polyethene roof protected the troughs, while in Expts D and E, they were covered by a plexiglass roof that allowed transmittal of UV radiation.

The sediment cores were distributed randomly among the 6 troughs, the total number of cores per experiment varying between 12 and 24 (Table 1). Green algal mats were added to 3 of the troughs ('with green algae'), while 3 were left without ('no green algae'). The added amount of fresh weight (FW) varied
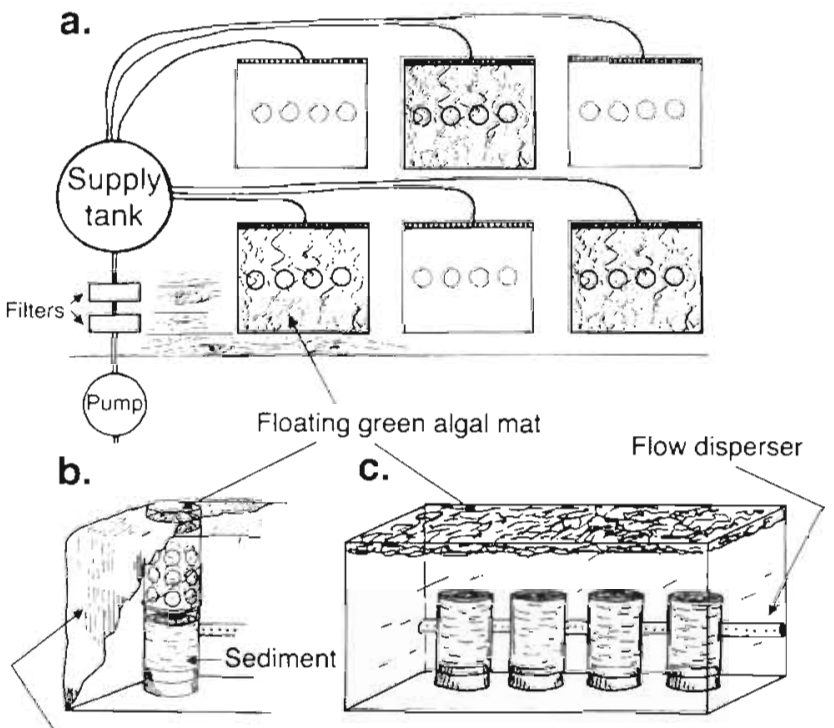

Black plastic

Fig. 1. Outdoor flow-through system used for incubating sediment cores with and without green algal mats. (a) Overview of the whole set-up (as seen from above). (b) Cores used in Expt A for measurements of nutrient fluxes; these consisted of a lower tube with sediment and an upper tube to hold the green algae in place. Holes (i.d. $20 \mathrm{~mm}$ ) in the upper tube enabled water flow between the green algal mat and the sediment surface. To measure flux rates, the flow was stopped by pulling a latex sleeve over the holes in the upper tube. (c) In Expts $B$ to $E$, only the lower tube was used and the whole water surface was covered with green algae

between 4.5 and $9 \mathrm{~kg} \mathrm{~m}^{-2}$ in the 5 experiments, corresponding to a dry weight (DW) of $\sim 340$ to $590 \mathrm{~g} \mathrm{~m}^{-2}$ (Table 1). In all experiments, the green algae were fresh and green, and were kept afloat by oxygen bubbles. In terms of DW per $\mathrm{m}^{2}$, the amount of green algae did not change significantly relative to the amout added initially during Expts $A, B$ and $C$. No final DW values exist from Expts $D$ and $E$, but FW values indicated a slight decrease (25\%) in Expt D, and a doubling in Expt E.

Table 1. Duration, treatment (algal load in dry weight, DW), and variables measured in the 5 experiments. PP: primary productivity as measured by ${ }^{14} \mathrm{C}$ uptake

\begin{tabular}{|c|c|c|c|c|c|c|c|c|c|c|c|}
\hline \multirow[t]{2}{*}{ Expt } & \multirow{2}{*}{$\begin{array}{l}\text { Duration } \\
\text { (d) }\end{array}$} & \multirow{2}{*}{$\begin{array}{l}\text { No. of } \\
\text { cores }\end{array}$} & \multirow{2}{*}{$\begin{array}{c}\text { Treatment } \\
\text { (g algal } \\
\text { DW m }{ }^{-2} \text { ) }\end{array}$} & \multicolumn{8}{|c|}{ Variables } \\
\hline & & & & Chl a & Algae & Meiofauna & Bacteria & $\begin{array}{l}\mathrm{O}_{2} \text { in } \\
\text { water }\end{array}$ & $\begin{array}{l}\mathrm{O}_{2} \text { profiles } \\
\text { in sediment }\end{array}$ & $\begin{array}{l}\text { Inorganic } \\
\text { nutrients }\end{array}$ & PP \\
\hline A & 21 & 24 & 436 & - & - & - & - & - & & - & \\
\hline B & 11 & 18 & 344 & - & - & - & & - & & & \\
\hline C & 11 & 18 & 519 & • & - & - & & - & - & & \\
\hline $\mathrm{D}$ & 14 & 18 & 588 & $\bullet^{\mathrm{a}}$ & - & & & & - & & - \\
\hline E & 41 & 12 & 547 & • & - & - & & & - & & \\
\hline
\end{tabular}


As nutrient fluxes were measured in Expt $A$, the setup differed from the subsequent 4 experiments. In Expt $A$, round pieces, with the same diameter as the cores, were cut out from the green algal mats and placed in each of 12 individual tubes (Fig. 1b), while in the remaining experiments the entire water surface of each trough was covered by a continuous green algal mat (Fig. 1c). In Expt $A$, the green algae were kept in place by a second transparent PVC tube which was placed on top of each sediment core so that the edges of these upper tubes were above the water surface (Fig. 1b). Holes (i.d. $20 \mathrm{~mm}$ ) in the upper tubes enabled water flow between the macroalgal mat and the sediment surface. The cores with no added algae were also equipped with an upper tube. To prevent light penetration through the transparent walls of the tubes, the troughs were covered with black plastic, with holes for the protruding upper tubes

Light: In Expts A, B and C, PAR was measured using a quantum scalar irradiance meter (Biospherical Instruments). In Expts D and E, an International Light photometer (IL 1400) equipped with flat PAR, UV-A and UV-B sensors was used.

Sampling and analyses: Samples for sediment variables were taken about once a week, except in Expt E, where samples were taken at the start and the end of the experiment. At each sampling, 1 core from each of the 6 troughs, i.e. 3 from each treatment, were collected. After measuring oxygen profiles (Expts $\mathrm{C}$ to $\mathrm{E}$ ), between 8 and 14 subsamples (depending on the number of measured variables) were taken from each core. As the microbial mat was cohesive, the subsamples were taken with a sharpened circular punch (i.d. $9 \mathrm{~mm}$ ). To make punching easier, pieces of the mat $(2$ to $3 \mathrm{~mm}$ thick) were cut out with a scalpel and carefully placed in a petri dish. After subsampling, the cores were discarded, so that no core was sampled more than once.

$P O C$ and $P O N$. The content of particulate organic carbon and nitrogen in the green algal mat and the microbial mat was measured with an elemental analyser as described in Nilsson et al. (1991).

Pigments. Chl a content was determined spectrophotometrically and corrected for pheopigments. Three subsamples from each core were pooled and extracted with $15 \mathrm{ml} 95 \%$ acetone overnight in a refrigerator. After $5 \mathrm{~min}$ of ultrasonication, the analysis proceeded according to Lorenzen (1967).

In Expt $D$, the ratios of chl $c_{1+2}$, fucoxanthin and diadinoxanthin+diatoxanthin to chl a were analysed by HPLC. Two subsamples per core were stored at $-80^{\circ} \mathrm{C}$, extracted in $100 \%$ acetone for $48 \mathrm{~h}$ at $-18^{\circ} \mathrm{C}$, ultrasonicated for $5 \mathrm{~min}$ and filtered through a $0.5 \mu \mathrm{m}$ polytetrafluorethylene (PTFE) syringe filter into amber vials. The vials were kept cool on an autosampler $\left(<0^{\circ} \mathrm{C}\right)$ and analysed within $12 \mathrm{~h}$. The analyses were made according to Wright et al. (1991). Pigment peaks were identified by comparing retention times and absorbance spectra (400 to $750 \mathrm{~nm}$, Linear 206 detector) with known pigments from several unialgal cultures.

Microalgal biomass. For cell counts, 2 samples from each core were pooled. After dilution, the algae in 2 fractions were counted in an epifluorescence microscope. After shaking the sample by hand for $1 \mathrm{~min}$, all living cells $>50 \mu \mathrm{m}$ in two to four $40-60 \mu \mathrm{l}$ subsamples were counted directly on a microscope slide. After ultrasonication for $12 \mathrm{~min}(35 \mathrm{kHz})$, the remaining cells were counted as previously described by Sundbäck \& Snoeijs (1991). For taxa $>50 \mu \mathrm{m}$, the dimensions of $\sim 30$ cells were measured to obtain a mean biovolume. For naviculoid shapes, which dominated the samples, the formula for a parallelepiped was used and corrected by a factor of between 0.56 and 0.9 depending on the shape of the cell. Biovolumes of smaller cells were based on previous biovolume calculations (see Sundbäck \& Snoejis 1991).

Meiofaunal biomass. From each core, 3 samples were taken, pooled, and preserved in $4 \%$ boraxbuffered formaldehyde containing bengal rose. Meiofauna were extracted by decantation, sieved and sorted into major taxa and counted as described in Sundbäck et al. (1990). Meiofaunal biomass was calculated according to Widbom (1984)

Bacterial biomass. Three replicate samples from each core were preserved with $0.2 \mu \mathrm{m}$ filtered $4 \%$ formaldehyde, stained with acridine orange, counted and measured as described by Sundbäck et al. (in

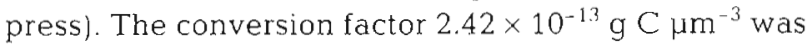
used (Moriarty 1990).

Primary productivity in the sediment. In Expt D, primary productivity was measured by ${ }^{14} \mathrm{C}$ labelling Two punched-out pieces of the microbial mat from each core were incubated separately in $25 \mathrm{ml}$ glass vials. A technique in which radiolabel is percolated into intact sediment (Jönsson 1991), used in some of our previous experiments, was not applicable, as the cohesiveness of the mats prevented efficient labelling by percolation. The samples were incubated for $2 \mathrm{~h}$ in the experimental troughs under the same light conditions as the sediment cores of the 2 treatments, i.e. with and without a green algal cover. Being cohesive, the mat pieces were not disrupted during the incubation. For details on further handling of ${ }^{14} \mathrm{C}$ samples, see Sundbäck et al. (1990).

Oxygen. Oxygen concentrations in the water column above the sediment cores were measured with an OxyGuard Mb III sensor (1993) or WTW oxygen electrode Model EOT 196 (1994). Oxygen microsensors with a guard cathode (Revsbech 1989) were used to measure oxygen microprofiles in the sediment. As the microsensor system became operable in August 1993, profiles 
were measured only in Expts C, D and E. The profiles were measured under standardized light conditions (ca $240 \mu \mathrm{mol}$ photons $\mathrm{m}^{-2} \mathrm{~s}^{-1}$ ) in the laboratory (see Jönsson et al. 1994). Measurements were made at intervals of 100 to $200 \mu \mathrm{m}$, from $1 \mathrm{~mm}$ above the sediment surface down to a level in the sediment where there was no oxygen left (between 1000 and $4000 \mu \mathrm{m}$ ). Three profiles per core were measured.

Inorganic nutrients. To measure flux rates of $\mathrm{NH}_{4}{ }^{+}$, $\mathrm{NO}_{3}{ }^{-}+\mathrm{NO}_{2}{ }^{-}, \mathrm{PO}_{4}{ }^{3-}$ and $\mathrm{Si}(\mathrm{OH})_{4}$, water exchange in the cores was stopped between ca 10:00 and 18:00 h (day value) and between 22:00 and 04:00 h (night value) by pulling a latex sleeve (the cuff of a latex glove) over the holes in the upper tube (Fig. 1b). Water samples from the cores were taken at the beginning and at the end of the period of flow stoppage. When sampling, the water was gently stirred. After the first sampling, the removed water volume $(300 \mathrm{ml})$ was replaced by water from the supply tank. This water was also analysed. Nutrients were analysed immediately in unfiltered water according to methods described in Grasshoff et al. (1983).

Statistical analyses. As time could not be used as an independent factor, treatment effects were tested using a 1-factor ANOVA for each sampling occasion. Cochran's test was used to check homogeneity of variances (Winer et al. 1991), and if found to be heterogeneous, the data were $\ln (x)$-transformed. A nested ANOVA was calculated for the oxygen profiles using maximum oxygen concentration of each profile and the corresponding sediment depth as variables. Differences were accepted as significant at $p<0.05$.

\section{RESULTS}

\section{Field measurements}

Light below the green algal mats was only 1 to $3 \%$ of the surface light, while with no macroalgal cover, 70 to $90 \%$ of surface PAR reached the sediment surface. During daytime, the water below the green algae was supersaturated with oxygen (Fig. 2a), values being higher just below the mats than above the mats. At night, oxygen saturation decreased to minimum values of $\sim 60 \%$, i.e. not below what is considered hypoxic conditions $(30 \%)$. Water flow (checked using fluorescein dye) among the green algae was roughly $1.6 \mathrm{~cm}$ $\mathrm{s}^{-1}$, i.e. $1 / 6$ of that in the freely flowing water of the trench. At noon, temperatures of up to $25^{\circ} \mathrm{C}$ were recorded in the algal mats, while the temperature was generally 5 to $6^{\circ} \mathrm{C}$ lower in the free-flowing water. Temperature decreased $\sim 3^{\circ} \mathrm{C}$ in a gradient from the surface of the green algal mat to the sediment surface. Inorganic nutrient concentrations were low: $\mathrm{NH}_{4}{ }^{+}$ $<1.5 \mu \mathrm{M}, \quad \mathrm{NO}_{3}{ }^{-}+\mathrm{NO}_{2}<1 \mu \mathrm{M}, \quad \mathrm{PO}_{4}{ }^{3-}<0.1 \mu \mathrm{M}$, and

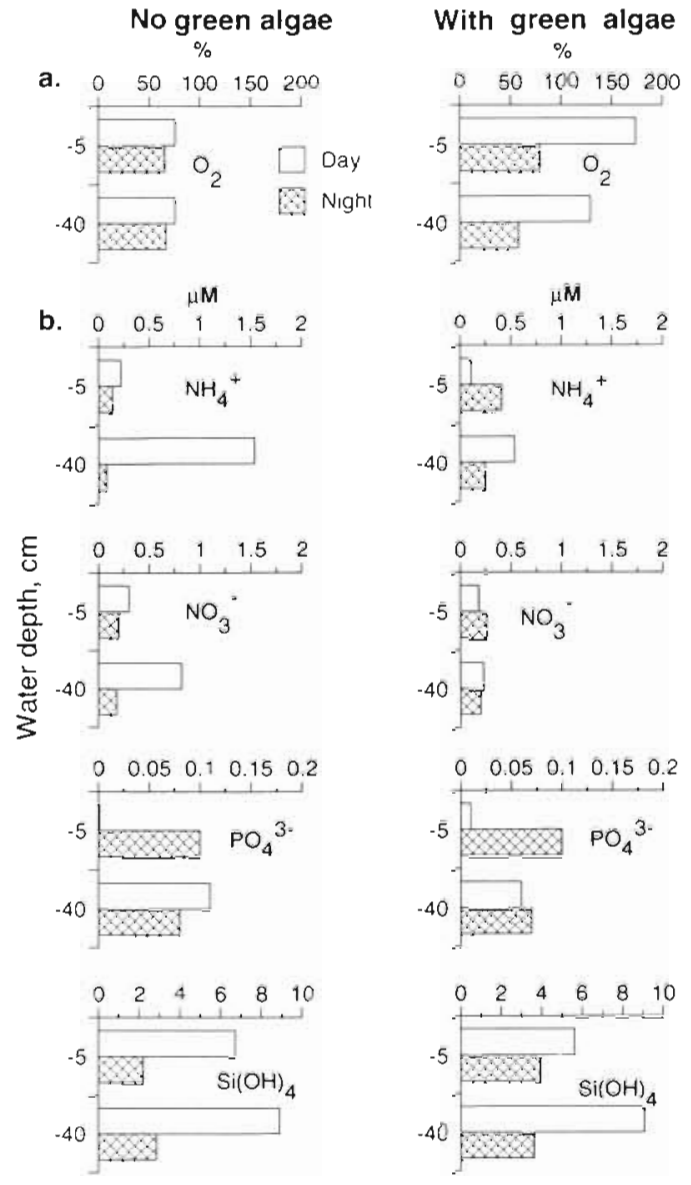

Fig. 2. (a) In situ oxygen saturation and (b) inorganic nutrient concentration in a water column without and with floating green algal mats. Values shown are from just below the green algal mat $(5 \mathrm{~cm}$ water depth) and just above the sediment surface $(40 \mathrm{~cm}$ water depth). Day values were sampled at $18: 30 \mathrm{~h}$ on July 5 and night values at sunrise $(04: 30$ h) on July 6

$\mathrm{Si}(\mathrm{OH})_{4}<9 \mu \mathrm{M}$ (Fig. 2b). Phosphate values were at the detection limit. Although the measurements cannot be treated statistically, no obvious differences between the area with and without mats were found (Fig. 2b). The apparently higher $\mathrm{N}$ and $\mathrm{P}$ concentrations at the bottom in a situation with no green algae may have been due to a higher density of bivalves in this area of Daftö Bay.

\section{The microbial mats}

Although the microbial mats were only a few $\mathrm{mm}$ thick, their organic carbon content per $\mathrm{m}^{2}$ was within the same order of magnitude as that of the green algal mats. For example, in Expt A, their mean POC content was 50 to $70 \mathrm{~g} \mathrm{C} \mathrm{m}^{-2}$ as compared with 50 to $100 \mathrm{~g} \mathrm{C}$ $\mathrm{m}^{-2}$ for the green algal mats. Occasionally up to $\sim 25 \%$ 


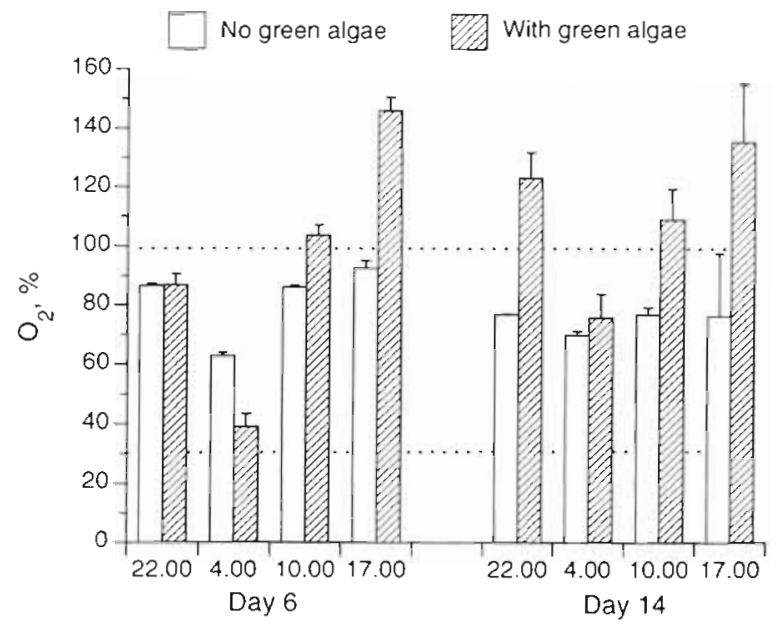

Fig. 3. Diel variation of oxygen saturation in the overlying water of sediment cores without and with green algal mats (436 $\mathrm{g} \mathrm{DW}^{-2}$ ) in Expt A. Numbers on $x$-axis denote time of measurements. Each bar shows mean $+\mathrm{SE}$ of 3 replicate cores

\section{$\operatorname{Expt} A$}

Because the set-up of Expt A differed from that of the subsequent experiments, the results are presented separately. The main difference was that the light climate between the treatments differed less in Expt $A$, because of the shading of the upper tube and the plastic cover: in cores with green algae, $6 \%$ of surface light reached the sediment. In cores without green algae. this value was $12 \%$.

\section{Oxygen concentrations and nutrient fluxes}

During daytime, oxygen values of the overlying water were higher in corcs with grcen algae than in cores with only sediment (Fig. 3; only values for Days 6 and 14 are shown). The undersaturated water in cores without green algae suggests high respiration rates in the sediment. On the other hand, the water from the supply tank was slightly undersaturated. Diel fluctua-

of this carbon consisted of epipelic diatoms The cohesiveness of the microbial mats indicated a high content of extracellular polysaccharides (EPS; Underwood et al. 1995), produced mainly by diatom movement. The biomass of microorganisms was dominated by autotrophs, microalgal biomass being initially 6 to 15 times (range for all experiments $\sim 2$ to $12 \mathrm{~g} \mathrm{C} \mathrm{m}^{-2}$ ) that of the meiofauna (range $\sim 0.2$ to $1 \mathrm{~g} \mathrm{C} \mathrm{m}^{-2}$ ) and 30 times that of the bacteria $\left(\sim 0.4 \mathrm{~g} \mathrm{C} \mathrm{m}^{-2}\right)$. The large (300 to $400 \mu \mathrm{m})$ motile, sigmoid diatom Gyrosigma balticum (Ehrenberg) Rabenhorst was the dominant species (cf. Figs. 5 \& 6). The behaviour of this species under submerged conditions has been described by Jönsson et al. (1994). During 1993 (Expts A to C), G. balticum co-occurred with another equally large sigmoid species, Pleurosigma formosum W. Sm. The biomass of the algal size fraction <50 $\mu \mathrm{m}$ was, particularly in 1994, dominated by the centric diatom Paralia sulcata (Ehrenberg) Cleve. Other common taxa among smaller diatoms were Navicula species within the size range 20 to $40 \mu \mathrm{m}$, and small Fragilariaceae spp. (cf. Sundbäck \& Snoeijs 1991). The major meiofaunal taxa were nematodes, juvenile oligochaetes and polychaetes, and occasionally foraminiferans. High variances in meiofaunal biomass among replicate cores was mainly caused by the oligochaete Paranais litoralis (Müller), which is known to have a patchy distribution (P. Nilsson pers. comm.).
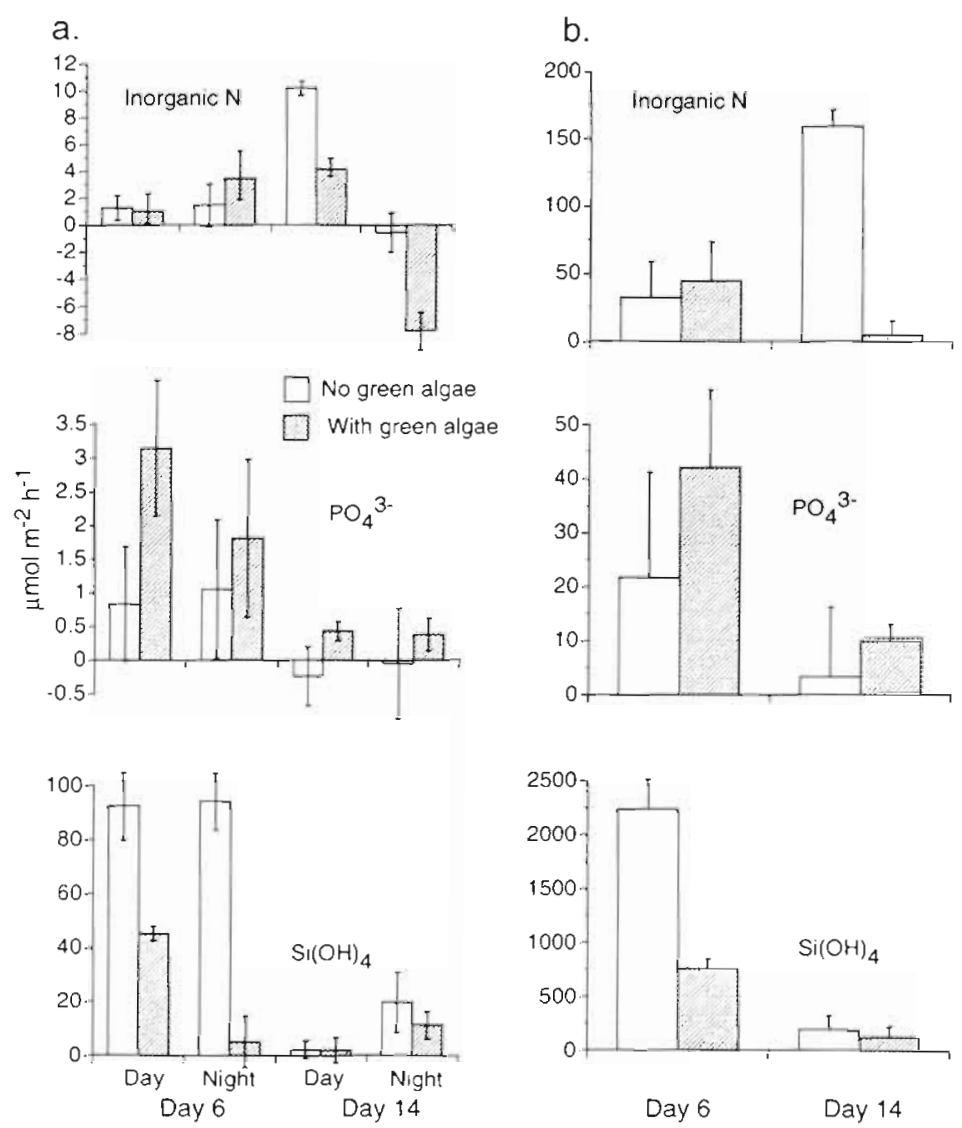

Fig. 4. Fluxes of inorganic nutrients in Expt A. In (a), hourly flux rates are shown separately for day and night. Day values were measured between 10:00 and 18:00 h and night values between $22: 00$ and $04: 00 \mathrm{~h}$. In (b), flux rates integrated over a $24 \mathrm{~h}$ period are shown. Each bars shows mean $(+\mathrm{SE})$ of 3 replicate treatments. For treatments see Table 1 and 'Materials and methods' 
tions were more pronounced for cores with green algae, but oxygen concentrations below the critical $30 \%$ level of saturation (hypoxia) were not found.

Fluxes of inorganic nutrients are shown both as mean hourly values for the day and night period, respectively (Fig. 4a), and as fluxes integrated over a $24 \mathrm{~h}$ period (Fig. 4b). The latter fluxes were calculated by multiplying day values by $16 \mathrm{~h}$, and night values by $8 \mathrm{~h}$, based on insolation values for the experimental period. Fluxes were generally positive. If fluxes of $\mathrm{NO}_{3}{ }^{-}+\mathrm{NO}_{2}{ }^{-}$and $\mathrm{NH}_{4}{ }^{+}$were considered separately, no consistent trend was found between day and night, or between treatments. As both fluxes were within the same order of magnitude, they were pooled to obtain an overview of $\mathrm{N}$ flux (Fig. 4a). On Day 6, there was no significant difference between the 2 treatments, while on Day 14, significantly more $\mathrm{N}$ was released (day) or less taken up (night) in cores without green algae. This significant difference was also seen for the 24 h rates (Fig 4 b). No significant effects were found for $\mathrm{PO}_{4}{ }^{3-}$ Significantly more silica was released from the noalgae treatments on Day 6 , both day and night, but not on Day 14

\section{Response of microorganisms}

The sediment surface below the macroalgae often appeared darker and more cohesive than that of cores with no green algal cover, but this difference was not as consistent as in Expts B to $\mathrm{E}$. The initial microalgal bio-

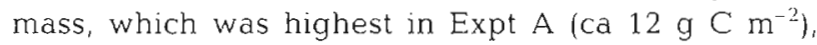
showed a declining trend in both treatments. Gyrosigma balticum and Pleurosigma formosum made up $>80 \%$, both being equally important (Fig. 5). No significant effect of green algae on either microalgal biomass or composition was found (Fig. 5). Chl a content (Fig. 5) and the algal $\mathrm{C} / \mathrm{chl}$ a ratio (range $\sim 18$ to 44 ; mean $\pm \mathrm{SE}$ : $33.7 \pm 1.9$; not shown) were also not affected

The meiofaunal biomass varied between ca 400 and $1100 \mathrm{mg} \mathrm{C} \mathrm{m}^{-2}$ and no significant effect of treatment on the total biomass was found (Fig. 5). Bacterial biomass, measured only for the initial and final dates, ranged from 430 to $690 \mathrm{mg} \mathrm{C} \mathrm{m}^{-2}$ and was also not significantly affected by the green algal cover (Fig. 5)

At the end of the experiment, the POC content of the sediment $\left(\sim 70 \mathrm{~g} \mathrm{~m}^{-2}\right)$ was not significantly different between the 2 treatments.
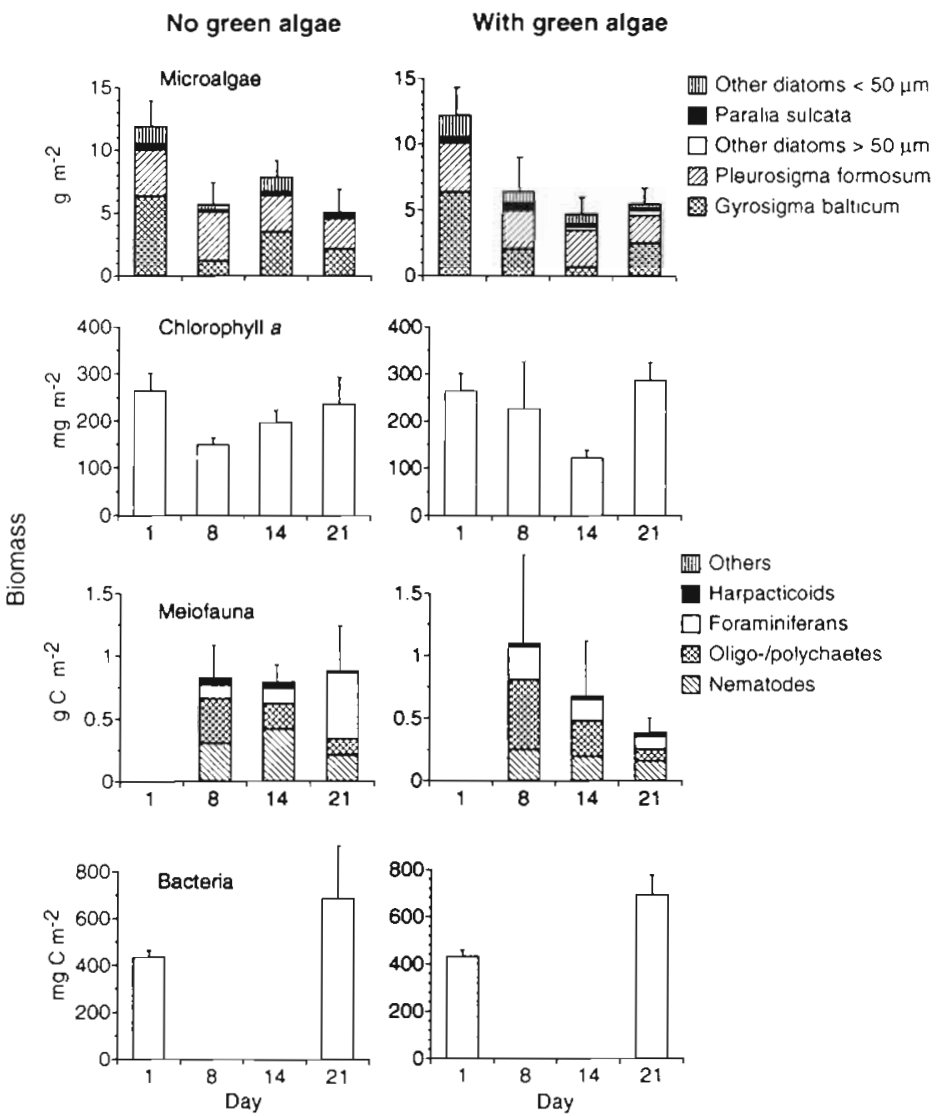

Fig. 5. Biomass of microalgae, chl a content and biomass of meiofauna and bacteria in the microbial mat in Expt A. Each bar shows mean (+SE) of 3 replicate cores. For treatments see Table 1

\section{Expts B to E}

As the absence of significant treatment effects in Expt A was somewhat surprising, a series of new experiments was conducted, focusing mainly on the response of the microalgae. In contrast to Expt $A_{2}$, the entire surface of the experimental containers was coverered with a continuous green algal mat. This created light conditions similar to those in situ, the light quantity varying between $<1$ and $4 \%$ of that in cores without green algae. Measurements with UV sensors in Expts D and E showed that the green algae effectively blocked out $\sim 99 \%$ of the UV-A and UV-B radiation

The general absence of a negative effect on the microbial biomass was confirmed in all subsequent experiments, even in the longest one, which lasted for $6.5 \mathrm{wk}$ (Expt E). On the contrary, the microalgae seemed to be initially stimulated in some experiments.

\section{Microalgae}

The first visible response of the microbial mats was that the sediment surface in cores containing green algae became brown while that without green algal cover turned grey- 

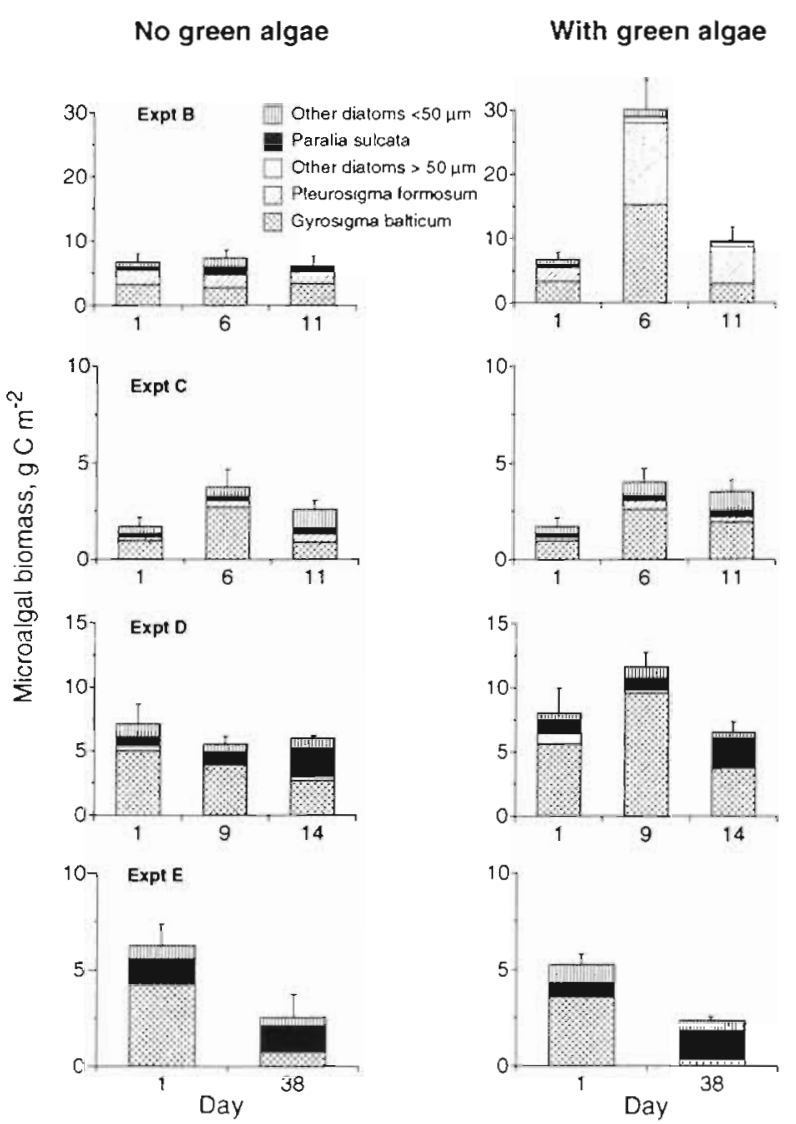

Fig. 6. Biomass of microalgae in the microbial mat from cores without and with a cover of floating green algae in Expts B, C, $D$ and $E$. Each bar shows mean ( $+S E$ ) of 3 replicate cores. For treatments see Table 1

ish. For the microalgal community, either no significant effect on biomass and composition (Expts $C$ and E) was observed or the microalgal biomass appeared to be initially stimulated (Expts B and D) (Fig. 6).

Initially, the microalgal biomass varied between 1.7 (Expt C) and $8.2 \mathrm{~g} \mathrm{C} \mathrm{m}^{-2}$ (Expt D) (Fig. 6). In Expt B, the total algal biomass in cores below green algae increased significantly by a factor of $\sim 5$ within $6 \mathrm{~d}$, the increase being due to Gyrosigma balticum and Pleurosigma formosum. This stimulus was followed by a decline, and no significant difference was seen on the

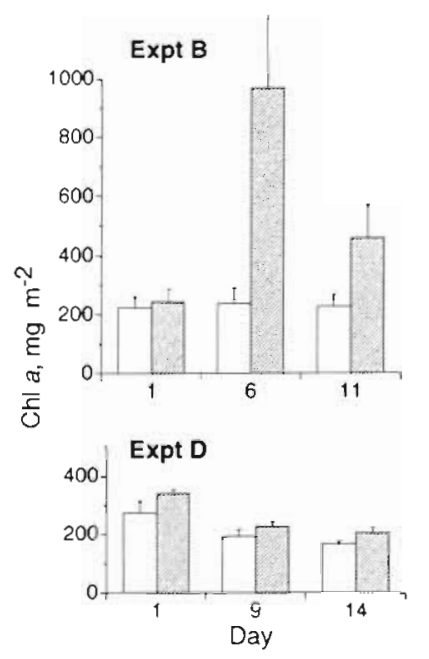

Expt C
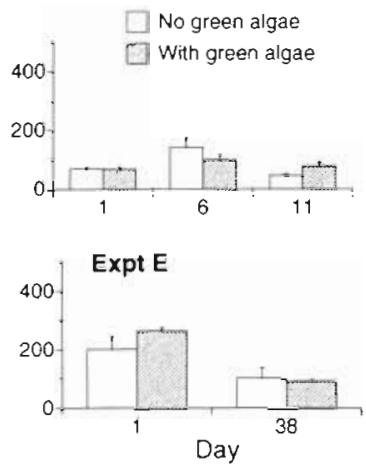

Fig. 7. Chl a content of the microbial mat in cores without and with a cover of floating green algae in Expts B, C, D and E. Each bar shows mean $(+\mathrm{SE})$ of 3 replicate cores. For treatments see Table 1

final day. Also in Expt D, a significant effect was observed in the middle of the experiment, whereas no significant effects were found in Expts $C$ or $E$.

In one experiment (Expt B), the chl a content of the microbial mat was significantly stimulated (Fig. 7). The algal $\mathrm{C} / \mathrm{chl}$ a ratio varied between 19 and 55 (mean \pm SE: $29.5 \pm 1.6$ ), but no significant differences were found. Pigment ratios, measured for Expt $D$, showed no significant effect either, although there was a tendency towards higher $\mathrm{chl} c_{1+2} / \mathrm{chl}$ a ratios and lower diadinoxanthin+diatoxanthin/chl a ratios in the treatments with algae (Table 2).

Measurements of potential primary production in Expt D showed that although $<1 \%$ of light penetrated through the green algae, primary productivity was still 30 to $50 \%$ of that in cores with no green algal mat (Fig. 8). The sediment oxygen profiles measured under standardized light conditions were used as indicators of microalgal photosynthetic activity in Expts C, D and E (Fig. 9). For afternoon measurements, there was a trend of greater oxygen peaks for microbial mats that had been under green algal cover, suggesting higher photosynthetic efficiency. This trend was statistically

Table 2. Ratios of different pignnents to chl a (mean \pm SE). The 2 treatments are no green algae (No g.a.) and with green algae (With g.a.). Initial ratıos (Day 1) are based on all 6 replicate cores (shown under 'No g.a.'); values for Days 8 and 13 are based on 3 cores per treatment

\begin{tabular}{|c|c|c|c|c|c|c|}
\hline & \multicolumn{2}{|c|}{ Fucoxanthin } & \multicolumn{2}{|c|}{ Chl $c_{1+2}$} & \multicolumn{2}{|c|}{ Diadinoxanthin+diatoxanthir } \\
\hline & Nog.a. & With g.a. & Nog.a. & With g.a. & No g.a. & With g.a. \\
\hline Day 1 & $1.12 \pm 0.26$ & & $0.41 \pm 0.13$ & & $0.31 \pm 0.05$ & \\
\hline Day 8 & $1.04 \pm 0.19$ & $1.02 \pm 0.14$ & $0.42 \pm 0.10$ & $0.44 \pm 0.07$ & $0.31 \pm 0.05$ & $0.20 \pm 0.03$ \\
\hline Day 13 & $1.21 \pm 0.17$ & $1.24 \pm 0.19$ & $0.43 \pm 0.07$ & $0.52 \pm 0.06$ & $0.35 \pm 0.05$ & $024 \pm 0.03$ \\
\hline
\end{tabular}




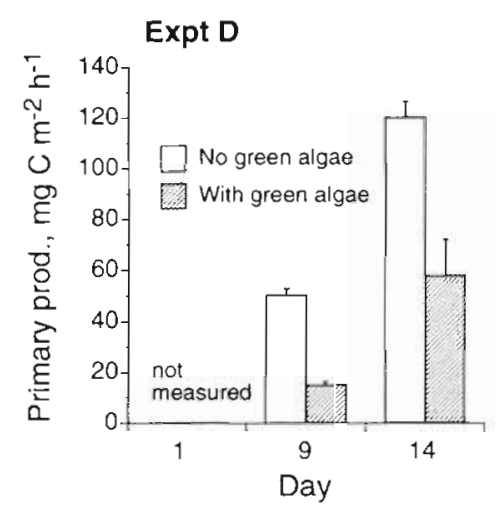

Fig. 8. Primary productivity $\left({ }^{14} \mathrm{C}\right.$ uptake) in the microbial mat from cores without and with a cover of floating green algae in Expt D. Each bar shows mean (+ SE) of 3 replicate cores. For treatments see Table 1

significant in Expts $C$ and D. In Expt E, the high variation among individual profiles masked any possible treatment effects.

Oxygen measurements in the overlying water column in Expt B showed a trend similar to that in Expt $A$, i.e. larger differences between day and night in troughs with green algae (not shown).
Meiofauna

The total meiofaunal biomass in Expts $B, C$ and $E$ varied between 200 and $4000 \mathrm{mg} \mathrm{C} \mathrm{m}^{-2}$ (Fig. 10). Values for Expt $D$ have been excluded because of a technical error. A significant stimulation of total meiofaunal biomass by the green algal cover was noted on Day 6 in Expt B. This effect was due to an increase of oligochaetes. In Expt C, significantly more meiofauna was found in the cores without green algae on Day 11, whereas no significant effects were found in Expt E.

\section{DISCUSSION}

\section{Methods}

Sampling and moving cohesive microbial mats from their natural habitat into experimental containers could be expected to disturb the mats. A visual effect of the coring was that the edges of the microbial mats withdrew from the walls of the sampling tubes and curled up. However, 'new' diatom mats covering the entire core surface developed within a day, apparently
Fig. 9. Oxygen microprofiles of the microbial mat in cores without and with a cover of floating green algae in Expts C, D and E. Each curve is based on 3 profiles measured in each of 3 replicate cores. SE of mean is shown. Morning measurement in Expt $\mathrm{C}$ was made at $\sim 04: 30 \mathrm{~h}$ and evening measurements between 17:00 and 19:00 h

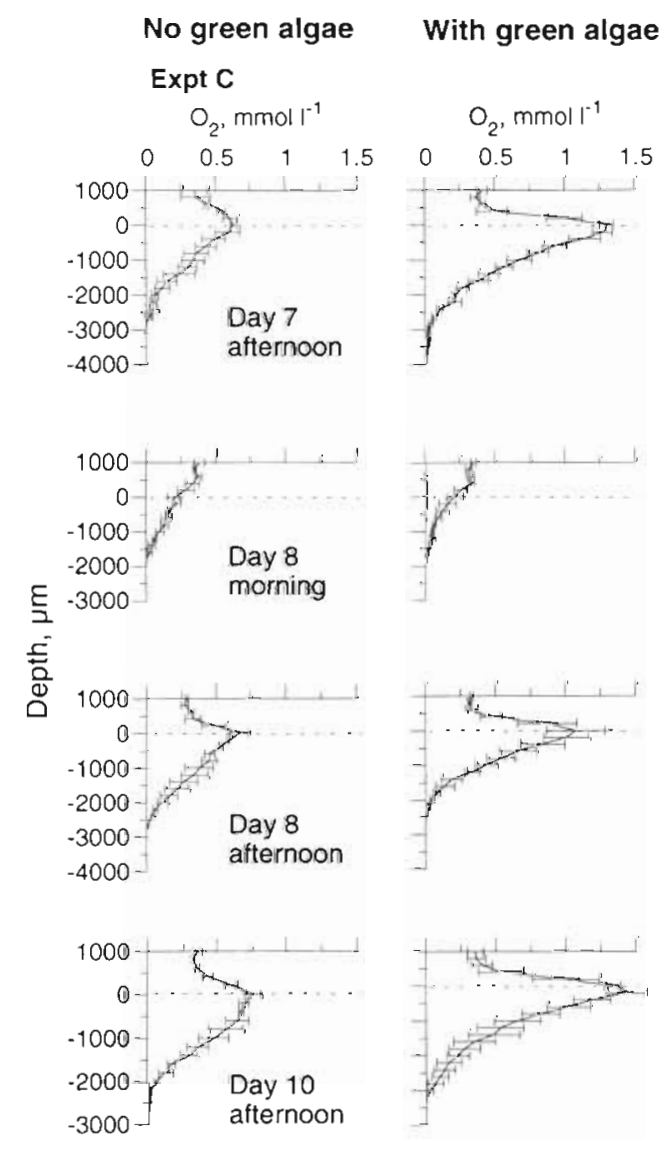

With green algae

\section{Expt D}

$\mathrm{O}_{2}, \mathrm{mmol} \mathrm{I}^{-1}$
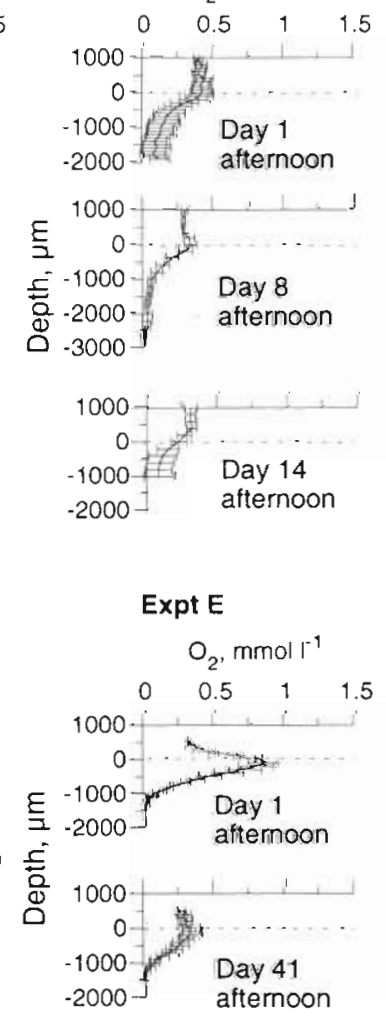
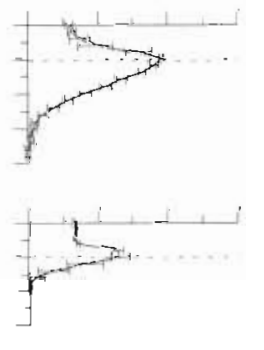

$\mathrm{O}_{2}, \mathrm{mmol} \mathrm{I}^{-1}$
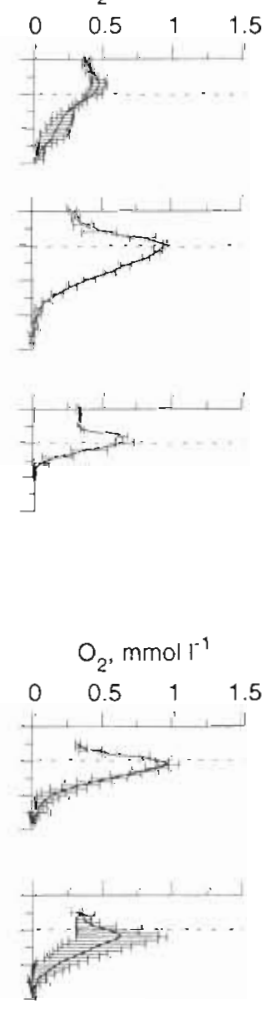
through diatom migration. We observed a similar rapid recolonization of Gyrosigma mats in previous laboratory experiments in which flaking was simulated (unpubl. obs.). Even when the whole mat was removed, the 'bare' sediment surface was partly recolonized by Gyrosigma cells migrating up from below the sediment surface.

Moving sediment from in situ water flow conditions to the more stagnant conditions of the flow-through troughs probably increased the thickness of the diffusive boundary layer above the sediment. However, the healthy appearance of the sediment surface, and the fact that biomass values increased in some experiments, suggest that the experimental conditions were not too unnatural for a sheltered atidal situation. The natural patchiness of the unicrobial indts, on the other hand, created a large variation in biomass values between replicate cores, lowering the power of statistical tests. Generally, the need for a large number of replicates is an unavoidable problem when using intact sediment instead of creating microcosms from homogenized sediment.

\section{Effects on the microscopic community}

With the exception of ${ }^{14} \mathrm{C}$ uptake, none of the experiments suggested any significant negative effect of the green algal mat on the autotrophic component of the microbial mats. The meiofaunal response was not as consistent, showing a slight negative effect in one experiment. Bacteria were not affected. In Expt $A$, the absence of a significant effect on microalgae could be explained by the small difference in the light climate between the 2 treatments. However, the trend of no negative effect persisted through all the subsequent 4 experiments in spite of the substantially decreased light quantity below the green algae. In fact, the only consistent pattern reflecting treatment was the difference in sediment surface colour.

Again, our experiments demonstrated the robustness of the microscopic community of shallow-water sediments. Previous experiments have also pointed at an inherent delay ( 2 to $3 \mathrm{wk}$ ) in the response of microbial sediment communities to changes in e.g nutrient supply, accumulation of organic matter and bioturbation (Levinton 1985, Sundbäck et al. 1990, Nilsson et al. 1991, Jönsson et al. 1993). The already high density of the sediment microbial community may be one explanation. Moreover, the presence of extracellular polysaccharides (EPS) may increase the inertia against changes in nutrient resources (Decho 1994, Freeman \& Lock 1995). However, as light, the prerequisite for photosynthesis, was the resource most drastically changed in our experiments, a measurable response of
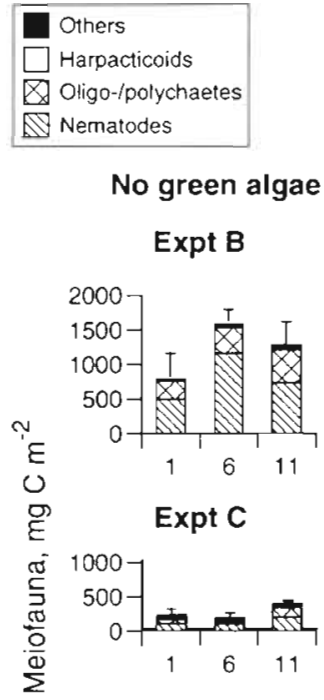

Expt $\mathbf{E}$

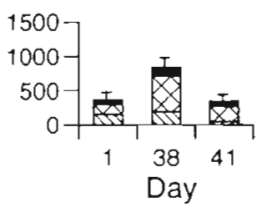

With green algae
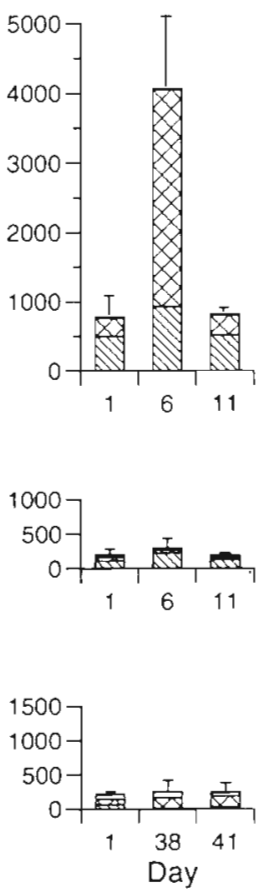

Fig. 10. Blomass of meiofauna in the microbial mat from cores without and with a cover of floating green algae in Expts B, C and E. Each bar shows mean ( + SE) of 3 replicate cores. For treatments see Table 1

the phototrophic biomass within a few weeks could have been expected. However, possible effects on the heterotrophic components (meiofauna and bacteria) are probably indirect, partly mediated through trophic links, and therefore slower.

The difference in sediment colour points to 2 aspects of the light climate. The grey colour of the unshaded sediment could be interpreted as a response to harmfully high light levels, while the dark colour of the shaded cores could reflect shade adaptation. Thus, the green algal mat may have functioned as a protective shield against a harmful quantity, or quality, of light. Hypothetically, not only PAR but also ultraviolet radiation (UVR) may have been involved; UV-B and UV-A were almost fully absorbed by the green algae. It has been shown that both UV-A and UV-B can induce downward migration of cyanobacteria (Bebout \& Garcia-Pichel 1995). However, at the same time, being below the green algal mats also implied that the diatom community had to adapt to a substantial decrease (>90\%) in light levels.

The change in sediment colour was fast and appeared to be caused by vertical migration of Gyrosigma balticum cells as a response to changed light climate. When 'brown cores' were moved from 
below algal mats to full sunlight, they turned grey within an hour. Moreover, when cores were studied in a stereomicroscope, more $G$. balticum cells were always seen on the sediment surface in shaded cores than in unshaded ones. We observed similar colour changes during midday in the field. Vertical migration is a well-known phenomenon on tidal coasts, where the diurnal endogenous rhythm is synchronized to the tidal cycle so that algae emerge to the surface at low tide (e.g. Paterson 1986, Happey-Wood \& Jones 1988) During the day, this often coincides with high light levels, and photoinhibition of microphytobenthos has seldom been noted in situ (for references see Blanchard \& Cariou-Le Gall 1994). However, we should be careful in comparing this behaviour with that of our constantly submerged diatom mats. For marine epipelic diatoms that are not subjected to regular tidal emersion, vertical migration may partly reflect avoidance of high light levels. Our previous observation that $G$. balticum cells remain in a vertical position on the sediment surface (Jönsson et al. 1994) also supports the idea of a different diatom behaviour in atidal and tidal situations. However, this remains to be verified.

Motility and vertical position within the sediment appear to be key mechanisms in the light acclimation of the microalgal community, as suggested previously by others (e.g. Blanchard \& Cariou-Le Gall 1994). Although we measured light at the sediment surface, we do not know what light climate the diatoms actually experienced during the experiments. The different vertical positioning of cells in shaded and unshaded cores may imply that the actual light climate of the diatoms did not differ much between the treatments. This may be one explanation for the lack of measurable effects.

Recently, more attention has been paid to photoacclimation of microphytobenthos, particularly on tidal coasts (Blanchard \& Montagna 1992, Pinckney \& Zingmark 1993, Blanchard \& Cariou-Le Gall 1994, MacIntyre \& Cullen 1995). The partly conflicting results of the above studies stress the need for more accurate measurements that take into account the fluctuating and dynamic system of microalgal films on sediment surfaces. The combined use of oxygen and spherical fiber-optic light microsensors has recently solved the technical problem (e.g. Ploug et al. 1993). However, our experiments were not designed for actual photoacclimation studies, which require construction of photosynthesis/irradiance curves. At noon in sunny weather, the sediment surface of unshaded cores in our experiments was exposed to $\sim 1300$ to $1600 \mu \mathrm{mol}$ photons $\mathrm{m}^{-2}$ $\mathrm{s}^{-1}$, while below the green algal mats, light was as low as 1 to $10 \mu \mathrm{mol}$ photons $\mathrm{m}^{-2} \mathrm{~s}^{-1}$. Published saturation values $\left(I_{k}\right)$ for intertidal diatoms during summer are within the range 400 to $900 \mu \mathrm{mol} \mathrm{m} \mathrm{m}^{-2} \mathrm{~s}^{-1}$, depending on the method used (for references, see above). Lower $I_{k}$ values have been reported for benthic diatom assemblages from sublittoral sediments ( 30 to $320 \mu \mathrm{mol} \mathrm{m} \mathrm{m}^{-2}$ $\mathrm{s}^{-1}$; Sundbäck \& Jönsson 1988). The lowest values have been reported for Antarctic benthic diatoms under ice $\left(<5 \mu \mathrm{mol} \mathrm{m}{ }^{-2} \mathrm{~s}^{-1}\right.$; Robinson et al. 1995). The latter studies suggest that benthic diatoms can maintain photosynthesis at very low light quantities.

Our sediment oxygen profiles measured under constant light conditions (whether saturating or not is not known) showed higher peaks for microbial mats underneath green algae. If this reflects higher photosynthetic efficiency, it suggests shade acclimation, but we do not know the strategy used for this. The observation that the decrease in ${ }^{14} \mathrm{C}$ uptake in Expt $\mathrm{D}$ was not proportional to the actual decrease in the light level also hints at shade acclimation. On the other hand, no significant changes in the $\mathrm{C} / \mathrm{chl}$ a ratios were observed. Pigment ratios showed a trend, although not significant; increased chl c/a ratios may indicate shade acclimation of diatoms beneath green algae and decreased diadino+diatoxanthin/chl a ratios may suggest decreased light stress in the shade of green algae (cf. Pfündel \& Bilger 1994). Light acclimation of algal communities can also be related to changed taxonomic composition or zonation of phototrophic taxa within the microbial mat (e.g Kühl et al. 1994). We could, however, not record any substantial changes in the proportions of major algal taxa. Still, the fact remains that primary production $\left({ }^{14} \mathrm{C}\right.$ uptake) was lower under green algal cover, and so there have to be some additional mechanisms that explain the absence of negative quantitative effects on the biomass level. The ${ }^{14} \mathrm{C}$ measurements were, on the other hand, not made with fully undisturbed sediment, and the results must be interpreted with caution.

Although an efficient light acclimation of the algal community appears to be important, there must be other mechanisms that explain the survival of the microbial mat for several weeks at the very low light levels. In biofilms, the polysaccharide matrix may buffer against DOC deprivation of bacteria (Freeman \& Lock 1995). Also, benthic diatoms can take up organic substrates, such as glucose and amino acids (Antia et al. 1991 and references therein, Nilsson \& Sundbäck in press). Some species can maintain growth in total darkness, while others exhibit photoheterotrophy (Admiraal \& Peletier 1979a). The large and rapid stimulation of both algae and meiofauna in Expt B cannot, however, be explained only by growth, taking into account the measured growth rates of epipelic diatoms and meiofauna (Gould \& Gallagher 1990, Nilsson 1992). Besides being a coincidence caused by an initial patchiness, horizontal and vertical movement of organisms leading to aggregation may be involved. 


\section{Nutrient fluxes}

The design of Expt A did not allow us to discriminate between sources and sinks of nutrient flux, and rates measured for cores with added green algae reflect a net flux for the whole sediment/macroalgal complex. However, despite this limitation, we have no indication that the sediment constituted a substantial nutrient source to the macroalgae, because of the following:

(1) Redox dependent release of $\mathrm{PO}_{4}{ }^{3-}$ or $\mathrm{NH}_{4}{ }^{+}$during the night did not occur, apparently because enough oxygen was produced during the day (mainly by green algae) to prevent anoxia during the night. This agrees with the results of Lavery \& McComb (1991), who found that loose banks of Chaetomorpha $(<312 \mathrm{~g} \mathrm{DW}$ $\mathrm{m}^{-2}$ j did not genter de sediment nutrient release. In neither treatment did our flux measurements show any clear diel pattern, i.e. with more autflux during the night, as found for sublittoral sediments (Sundbäck et al. 1991). When floating algal banks are present, they can also release nutrients. One further reason may be that we did not take measurements over $24 \mathrm{~h}$, and may have missed the period with the highest release rate (cf. Thybo-Christesen et al. 1993). This could explain why there was higher uptake or less release of $N$ during the night (cf. Fig 4a).

(2) Fluxes in cores containing only sediment were lower than published values for silty sediments (cf. Sundbäck et al. 1991, Reay et al. 1995), and largely within the range of those for sandy sediments on the Swedish west coast (Sundbäck et al. 1990, Nilsson et al. 1991, Jönsson et al. 1993). This is most probably a result of the nutrient demand of the extremely dense diatom mat at the sediment surface. Several studies have shown that benthic microalgae can to some extent control the nutrient flux between sediment and water (e.g. Andersen \& Kristensen 1988; for additional references see Rizzo et al. 1992, Reay et al. 1995). Thybo-Christesen et al. (1993), who studied nutrient fluxes and green algal mats in a shallow Danish bay, calculated that only $1 / 3$ of the $\mathrm{N}$ demand came from the sediment $\left(0.83 \mathrm{mmol} \mathrm{m} \mathrm{m}^{-2} \mathrm{~d}^{-1}\right)$. Our measured $\mathrm{N}$ fluxes in cores without green algae were $<20 \%$ of this value, at a maximum of $0.16 \mathrm{mmol} \mathrm{m}^{-2} \mathrm{~d}^{-1}$. A hypothesis that must be tested further is whether dense microalgal mats can control the growth of floating ephemeral algae in shallow water by suppressing nutrient outflux from the sediment. Significantly lower silica outflux in cores with macroalgae may reflect uptake by epiphytic diatoms

(3) If a major nutrient release did in fact occur, rapid uptake may have masked the fluxes. On the other hand, if the sediment was a major nutrient source, then we could have expected a net growth of the green algae. However, in all experiments but one (Expt E), either there was no net growth of green algae or there was a decrease in biomass. During Expt $E$, the algal biomass of the microbial mat decreased markedly, while biomass of meiofauna increased. This may have increased nutrient flux out of the sediment.

It appears that nutrients were efficiently recycled in the cores with sediment and green algae. Therefore we suggest that, when healthy, the 2 types of algal mat may function independently by internal recycling of nutrients. This agrees with the conclusion we made from a previous experiment on the effect of floating red algal mats on microbenthos (Sundbäck et al. 1990). The absence of negative effects, however, only applies to a situation with moderately thick, healthy green algal mats. The amounts of algae used in our experiments agree with those mcasurcd in situ by pihl et al. (in press) on the Swedish west coast. When the algal banks are dense, or when the green algal mats sink and decompose, effects on the sediment community below can be considerable (ct. Lavery \& McComb 1991). Following such anoxic conditions, benthic diatoms appear to play a key role in the recovery of the sediment community (Sundbäck at al. 1990), probably because of their high tolerance to anoxic conditions and sulfides (Admiraal \& Peletier 1979b, Kennett \& Hargraves 1985).

\section{CONCLUSIONS}

Benthic diatom mats do not appear to be outcompeted by average amounts of healthy floating green algal mats. One hypothesis, which must be confirmed by further experiments, is that shade adaptation and sediment supply of both inorganic and organic nutrients enable the microbial mats to exist, and perhaps even thrive under the 'shading roof' of the green algae. A further hypothesis to be tested is that well-developed microbial mats, by decreasing nutrient outflow from the sediment, may to some extent counteract the development of extremely thick green algal mats which rapidly create bottom anoxia.

The results also suggest some, still insufficiently understood, mechanisms of diatom-dominated microbial mats for adapting to life below another algal mat. Although vertical migration appears to be part of the strategy, more work is needed on the photoacclimation of sediment-inhabiting microalgae, particularly under atidal and subtidal conditions. Also, the quantitative importance of heterotrophy in natural benthic microalgal communities should be further investigated.

Acknowledgements. Financial support was provided by research grants from the Swedish Environmental Protection Agency, the Swedish Natural Science Research Council, the 
Marine Research Centre at Göteborg University, and the funds of Captain Stenholm, Adlerbertska and Helge Ax:son Johnsson. Dr Per Nilsson (Tjärnö Marine Biological Laboratory) gave advice on meiofauna identification. Agneta Persson made the drawings for Fig. 1. We thank 2 anonymous referees for constructive comments.

\section{LITERATURE CITED}

Admiraal W. Peletier H (1979a) Influence of organic compounds and light limitation on the growth rate of estuarine benthic diatoms. Br Phycol J 14:197-206

Admiraal W, Peletier H (1979b) Sulphide tolerance of benthic diatoms in relation to their distribution in an estuary. $\mathrm{Br}$ Phycol J 14:185-196

Andersen $F \varnothing$, Kristensen $E$ (1988) The influence of macrofauna on estuarine benthic community metabolism: a microcosm study. Mar Biol 99:591-603

Antia NJ, Harrison PJ, Oliveira L (1991) The role of dissolved organic nitrogen in phytoplankton nutrition, cell biology and ecology. Phycologia 30:1-89

Bebout BM. Garcia-Pichel F (1995) UVB-induced vertical migrations of cyanobacteria in a microbial mat. Appl Environ Microbiol 61:4215-4222

Blanchard GF, Cariou-Le Gall V (1994) Photosynthetic characteristics of microphytobenthos in Marennes-Oléron Bay, France: preliminary results. J Exp Mar Biol Ecol 182:1-14

Blanchard GF, Montagna PA (1992) Photosynthetic response of natural assemblages of marine benthic microalgae to short-and long-term variations of incident irradiance in Baffin Bay, Texas. J Phycol 28:7-14

Decho AW (1994) Exopolymers in microbial mats: assesssing their adaptive roles. In: Stal LJ, Caumette P (eds) Microbial mats. Structure, development and environmental significance. NATO ASI Series, Series G, Vol 35, SpringerVerlag, Berlin, p 215-227

den Hartog $C$ (1994) Suffocation of a littoral Zostera bed by Enteromorpha radiata. Aquat Bot 47:21-28

Fong P, Donohoe RM, Zedler JB (1993) Competition with macroalgae and benthic cyanobacterial mats limits phytoplankton abundance in experimental microcosms. Mar Ecol Prog Ser 100:97-102

Freeman C, Lock MA (1995) The biofilm polysaccharide matrix: a buffer against changing organic substrate supply? Limnol Oceanogr 40:273-278

Gould DM, Gallagher ED (1990) Field measurement of specific growth rate, biomass, and primary production of benthic diatoms of Savin Hill Cove, Boston. Limnol Oceanogr 35: $1757-1770$

Grasshoff K, Erhardt M, Kremling K (1983) Methods of seawater analysis, 2nd edn. Verlag Chemie, Weinheim

Happey-Wood CM, Jones P (1988) Rhythms of vertical migration and motility in intertidal benthic diatoms with particular reference to Pleurosigma angulatum. Diat Res 3:83-93

Isaksson I, Pihl L (1992) Structural changes in benthic macrovegetation and associated epibenthic faunal communities. Neth J Sea Res 30:1-7

Jeffrey DW, Brennan MT, Jennings E, Madden B, Wilson JG (1995). Nutrient sources for in-shore nuisance macroalgae: the Dublin Bay case. Ophelia 42:147-161

Jönsson B (1991) A ${ }^{14} \mathrm{C}$-incubation technique for measuring microphytobenthic primary productivity in intact sediment cores. Limnol Oceanogr 36:1485-1492

Jönsson B, Sundbäck K, Nilsson C (1994). An upright lifeform of an epipelic motile diatom: on the behaviour of Gyrosigma balticum. Eur J Phycol 29:11-15
Jönsson B, Sundbäck K, Nilsson P, Nilsson C, Swanberg IL, Ekebom J (1993) Does the influence of the epibenthic predator Crangon crangon L. (brown shrimpl extend to sediment microalgae and bacteria? Neth J Sea Res 31 $83-94$

Kennett DM, Hargraves PE (1985) Benthic diatoms and sulfide fluctuations: upper basin of Pettaquamscutt River, Rhode Island. Estuar Coast Shelf Sci 21:577-586

Kühl M, Lassen C, Jorgensen BB (1994) Optical properties of microbial mats: light measurements with fiber-optic microprobes. In: Stal LJ, Caumette P (eds) Microbial mats. Structure, development and environmental significance. NATO ASl Series, Series G, Vol 35, Springer-Verlag, Berlin, p 149-165

Lavery PS, McComb AJ (1991) Macroalgal-sediment nutrient interactions and their importance to macroalgal nutrition in a eutrophic estuary. Estuar Coast Shelf Sci 32:281-295

Levinton JS (1985) Complex interactions of a deposit feeder with its resources: roles of density, a competitor, and detrital addition in the growth and survival of the mudsnail Hydrobia totteni. Mar Ecol Prog Ser 22:31-40

Lorenzen CJ (1967) Determination of chlorophyll and pheopigments: spectrophotometric equations. Limnol Oceanogr 12:343-346

MacIntyre HL, Cullen JJ (1995) Fine-scale vertical solution of chlorophyll and photosynthesic parameters in shallowwater benthos. Mar Ecol Prog Ser 122:227-237

McComb AJ, Humphries R (1992) Loss of nutrients from catchments and their ecological impacts in the PeelHarvey estuarine system, Western Australia. Estuaries 15 $529-537$

Moriarty DJW (1990) Techniques for estimating bacterial growth rates and production of biomass in aquatic environments. Meth Microbiol 22:211-234

Nilsson C, Sundbäck K (in press) Amino acid uptake in natural microphytobenthic assemblages studied by microautoradiography. Hydrobiologia

Nilsson P (1992) The role of meiofauna in a marine shallowwater sediment community. Doctoral thesis, Göteborg University

Nilsson $P$, Jönsson B, Lindström Swanberg I, Sundbäck K (1991) Response of a marine shallow-water sediment system to an increased load of inorganic nutrients. Mar Ecol Prog Ser 71:275-290

Olafsson EB (1988) Inhibition of larval settlement to a soft bottom benthic community by drifting algal mats: an experimental test. Mar Biol 97:571-574

Paterson DM (1986) The migratory behaviour of diatom assemblages in a laboratory tidal micro-ecosystem examined by low temperature scanning electron microscopy. Diat Res 1:227-239

Pfündel E, Bilger W (1994) Regulation and possible function of the violaxanthin cycle. Photosynth Res 42:89-109

Pihl L (1989) Abundance, biomass and production of juvenile flatfish in southeastern Kattegat. Neth J Sea Res 24:69-81

Pihl L, Magnusson G, lsaksson I, Wallentinus I (in press) Distribution and growth dynamics of ephemeral macroalgae in shallow bays on the Swedish west coast. Neth $J$ Sea Res 35

Pinckney J, Zingmark RG (1993) Photophysiological responses of intertidal benthic microalgal communities to in situ light environments: methodological considerations Limnol Oceanogr 38:1373-1383

Ploug H, Lassen C, Jørgensen BB (1993) Action spectra of microalgal photosynthesis and depth distribution of spectral scalar irradiance in a coastal marine sediment of Limfjorden, Denmark. FEMS Microbiol Ecol 102:261-270 
Reay WG, Gallagher DL, Simmons GM Jr (1995) Sedimentwater column oxygen and nutrient fluxes in nearshore environments of the lower Delmarva Peninsula, USA. Mar Ecol Prog Ser 118:215-227

Revsbech NP (1989) An oxygen microelectrode with a guard cathode. Limnol Oceanogr 34:474-478

Rizzo WM, Lackey GL, Christian RR (1992) Significance of euphotic, subtidal sediments to oxygen and nutrient cycling in a temperate estuary. Mar Ecol Prog Ser 86:51-61

Robinson DH, Arrigo KR, Iturriaga R, Sullivan CW (1995) Microalgal light-harvesting in extreme low-light environments in McMurdo Sound, Antarctica. J Phycol 31. $508-520$

Rosenberg R, Elmgren R. Fleischer S, Jonsson P, Persson G, Dahlin H (1990) Marine eutrophication case studies in Sweden. Ambio 19:102-108

Sfriso A, Pavoni B, Marcomini A, Orio AA (1992) Macroalgae. nutrient cycles, and pollutants in the lagoon of Venice Estuaries 15:517-528

Sundbäck K, Enoksson V. Granéli W. Pettersson K (1991) Influence of sublittoral microphytobenthos on the oxygen and nutrient flux between sediment and water: a laboratory continuous-flow study. Mar Ecol Prog Ser 74:263-279

Sundbäck K, Jönsson B (1988) Microphytobenthic productivity and biomass in sublittoral sediments of a stratified bay, southeastern Kattegat. J Exp Mar Biol Ecol 122: $63-81$

Sundbäck K, Jönsson B, Nilsson P, Lindström I (1990) Impact of accumulating drıfling macroalgae on a shallow-water sediment system: an experimental study. Mar Ecol Prog Ser 58:261-274

Sundbäck K Snoeijs P (1991) Effects of nutrient enrichment on microalgal community composition in a coastal shallow-water sediment system: an experimental study. Botanica Mar 34:341-358

Thybo-Christesen M, Rasmussen MB, Blackburn TH (1993) Nutrient fluxes and growth of Cladophora sericea in a shallow Danish bay. Mar Ecol Prog Ser 100:273-281

Underwood GJC, Paterson DM, Parkes RJ (1995) The measurement of microbial carbohydrate exopolymers from intertidal sediments. Limnol Oceanogr 40:1243-1253

Widbom B (1984) Determination of average individual dry weights and ash-free dry weights in different sieve fractions of marine meiofauna. Mar Biol 75:101-109

Winer BJ, Brown DR, Michels KM (1991) Statistical principles in experimental design. McGraw-Hill Inc, New York

Wright SW, Jeffrey SW, Mantoura RFC, Llewellyn CA, Bjornlan T, Repeta D, Welschmeyer N (1991) Improved HPLC method for the analysis of chlorophylls and carotenoids from marine phytoplankton. Mar Ecol Prog Ser 77:183-196

Manuscript first received: November 28, 1995

Revised version accepted: February 6, 1996 